\title{
The Implementation of Project-Based Learning to Improve the Learning Interest and Student Achievement
}

\author{
Hamida Fauzia \\ Suparti \\ Sawitri Dwi Prastiti \\ Universitas Negeri Malang \\ Email: fauzia.hamida@yahoo.co.id
}

\begin{abstract}
The purpose of the research is project based learning model to improve student interest and achademic achievment of second grade of Social departement of State Senior High School 3 Blitar Through the implementation of project-based learning model. The research design is a Classroom Action Research (CAR) also using achademic achievment test and observation instruments. The research shows that the students learning interest and achademic achievment can be improved.
\end{abstract}

Keywords: Project-Based Learning Model, Learning Interest, Achademic Achievment

\begin{abstract}
Abstrak: Penelitian ini bertujuan untuk meningkatkan minat dan hasil belajar siswa kelas XI IPS 3 SMAN 3 Blitar melalui penerapan model project based learning. Penelitian ini merupakan Penelitian Tindakan Kelas (PTK) dengan menggunakan instrumen tes hasil belajar dan observasi. Hasil penelitian menunjukkan bahwa dengan menggunakan model project based learning dapat meningkatkan minat dan hasi belajar.
\end{abstract}

Kata kunci: Model Project Based Learning, Minat Belajar, Hasil Belajar.

Pembelajaran kurikulum 2013 adalah pembelajaran kompetensi dengan memperkuat proses pembelajaran dan penilaian autentik untuk mencapai kompetensi sikap, pengetahuan dan keterampilan. Prinsip pembelajaran pada kurikulum 2013 menekankan perubahan paradigma dari pembelajaran yang berpusat pada guru (Teacher Centered) menjadi pembelajaran yang berpusat pada siswa (Student Centered), pembelajaran yang sebelumnya bersifat verbalisme menjadi aplikatif serta proses belajar dapat berlangsung di rumah, di sekolah, dan di masyarakat. Harsono (2008:2) menyebutkan "Student Centered Learning merupakan strategi pembelajaran yang menempatkan siswa sebagai subyek atau peserta didik yang aktif dan mandiri, dengan kondisi psikologi sebagai adult learner bertanggung jawab sepenuhnya atas pembelajarannya, serta mampu belajar diluar kelas". Namun dalam penerapannya walaupun sudah menggunakan kurikulum 2013 pembelajaran di kelas masih lebih banyak bersifat verbalisme, mayoritas masih berpusat pada guru, sehingga guru masih sangat dominan saat proses pembelajaran.

Berdasarkan hasil observasi peneliti di kelas XI IPS 3 SMAN 3 Blitar dapat diperoleh hasil sebagai berikut: (1) minat dan kesadaran siswa untuk belajar masih rendah dibuktikan 
dengan minimnya aktivitas siswa di kelas, seperti bertanya, diskusi, mencatat, menulis karena siswa masih banyak yang tidak fokus saat kegiatan pembelajaran berlangsung, (2) model pembelajaran yang digunakan oleh guru mata pelajaran itu sendiri kurang bervariasi, (3) siswa kurang aktif dalam proses pembelajaran, dan (4) hasil belajar siswa masih rendah atau kurang dari KKM. Dari beberapa hasil yang diperoleh diatas, mengakibatkan siswa cenderung jenuh dan bosan saat pembelajaran berlangsung karena guru hanya menyampaikan dan menjelaskan materi di depan kelas saja. Perhatian guru pun tidak dapat sepenuhnya kepada siswa. Siswa hanya duduk dan mendengarkan guru menyampaikan materi dan tidak ikut berperan aktif saat proses pembelajaran berlangsung. Hasil belajar pada mata pelajaran Akuntansi dari 33 siswa terdapat sekitar 68\% siswa belum mencapai KKM dan harus mengikuti ujian remedial. Ujian remedial dilaksanakan karena tidak semua siswa memperoleh nilai yang sesuai dengan KKM yaitu 76.

Agar tercapai tujuan yang ingin dicapai pada implementasi kurikulum 2013 maka dilaksanakan dengan menggunakan pendekatan ilmiah (Scientific Approach), yaitu pembelajaran yang mendorong siswa lebih baik dalam melakukan pengamatan/observasi, bertanya, bernalar, mencoba dan mengomunikasikan/mempresentasikan (Maulipaksi, 2014; EH, 2013). Salah satu model pembelajaran yang dianggap dapat meningkatkan minat belajar siswa untuk mengikuti proses pembelajaran dengan baik dan meningkatkan pemahaman siswa mengenai materi akuntansi adalah model pembelajaran berbasis proyek atau project based learning. Pembelajaran berbasis proyek merupakan pendekatan pendidikan yang berfokus pada kreatifitas berfikir, pemecahan masalah, dan interaksi antara siswa dengan kawan sebaya untuk menciptakan dan menggunakan pengetahuan baru (Berenfeld dalam Rais, 2010). (Thomas dalam Fathurohman, 2015) mengemukakan bahwa prinsip pembelajaran berbasis proyek pada prosesnya mengarah kepada pencapaian tujuan, yang mengandung kegiatan inkuiri, pembangunan konsep, dan resolusi. Selain itu juga memuat proses perancangan, pembuatan keputusan, penemuan masalah, pemecahan masalah, discovery dan pembentukan model.

Penerapan model pembelajaran project based learning dalam pembelajaran ini memiliki tujuan untuk meningkatkan minat belajar siswa sehingga diharapkan juga hasil belajar yang didapatkan siswa maksimal. Minat Menurut Hidi \& Harackiewicz (2000), siswa yang tertarik pada apa yang mereka pelajari menunjukkan prestasi akademik yang lebih tinggi dan lebih mungkin mengingat materi tersebut dalam jangka panjang. Seringkali minat dan pengetahuan saling menguatkan: minat dalam sebuah topik tertentu memicu semangat 
untuk mempelajari lebih dalam tentang topik tersebut dan pengetahuan bertambah sebagai akibat dari proses pembelajaran itu pada gilirannya akan meningkatkan minat yang lebih besar lagi (Blumenfeld dalam Ormrod, 2009: 102). Tujuan penelitian ini adalah untuk mengetahui peningkatan minat belajar dan hasil belajar akuntansi siswa yang diberikan pembelajaran dengan menerapkan model project based learning.

\section{METODE}

Jenis penelitian ini menggunakan Penelitian Tindakan Kelas (PTK) karena dilakukan didalam kelas untuk memberikan tindakan tertentu agar dapat memperbaiki proses pembelajaran di kelas. Pendekatan penelitian ini menggunakan pendekatan kualitatif deskriptif. Menurut Sugiyono (2008:15) pendekatan kualitatif deskriptif adalah metode penelitian yang berlandaskan pada filsafat postpositivisme yang biasanya digunakan untuk meneliti pada kondisi objektif yang alamiah dimana peneliti berperan sebagai instrumen kunci. Subjek dalam penelitian ini adalah siswa kelas XI IPS 3 pada semester genap tahun pelajaran 2015/2016 dengan jumlah 33 orang. Sumber data yang digunakan adalah dari subyek penelitian, guru mata pelajaran, pengamatan, dan dokumentasi. Sedangkan alat yang digunakan adalah rencana pelaksanaan pembelajaran (RPP), lembar observasi, tes, dan dokumentasi. Teknik pengumpulan data pada penelitian ini menggunakan tes tulis dan hasil proyek kelompok siswa berupa makalah untuk mengetahui hasil belajar siswa.

Analisis data yang digunakan adalah metode Miles dan Huberman (dalam Sugiyono, 2009:247), yaitu reduksi data, penyajian data serta kesimpulan dan refleksi. Penelitian tindakan kelas yang digunakan dalam penelitian ini terdiri dari dua siklus. Sedangkan alur rancangan penelitian tindakan kelas ini dikembangkan oleh Kemmis dan Mc Taggart (Uno dkk, 2011:87) yang terdiri dari empat konsep, yaitu: (1) perencanaan, (2) tindakan, (3) pengamatan, dan (4) refleksi.

\section{HASIL dan PEMBAHASAN} HASIL

Hasil penelitian penerapan model pembelajaran Project Based Learning menggunakan dua siklus. Berdasarkan data dalam tindakan siklus I, dapat diketahui hasil yang diperoleh sebagai berikut. 


\section{Tahapan Project Based Learning Siklus I}

a. Penentuan Proyek

Tahapan Project Based Learning yang pertama yaitu penentuan proyek. Setelah guru menjelaskan materi mengenai jurnal penyesuaian yang berkaitan dengan transaksi deferral, guru membagi siswa menjadi 6 kelompok dan menjelaskan rangkaian proyek 1 secara global mengenai apa saja yang harus dilakukan siswa setiap tahapannya. Selanjutnya, guru meminta siswa untuk berdiskusi menentukan tempat observasi di perusahaan jasa serta memikirkan apa yang akan ditanyakan terkait dengan materi yang sudah dipelajari. Siswa juga diperbolehkan untuk bertanya materi diluar transaksi deferral dengan catatan materi tersebut tidak menyimpang jauh dari pelajaran akuntansi.

b. Perencanaaan langkah-langkah penyelesaian proyek

Siswa bersama dengan anggota kelompoknya setelah berdiskusi menentukan tempat observasi mereka menuliskannya di kertas beserta nama kelompok dan CP ketua kelompok. Sebelumnya guru juga telah mengingatkan kepada siswa untuk tidak memilih jenis usaha tambal ban dan diusahakan tidak sama tempat observasinya untuk setiap kelompok, diharapkan dengan begitu informasi yang akan didapat akan lebih kaya. Guru juga mengingatkan kepada siswa untuk menyiapkan daftar pertanyaan atau rumusan masalah yang nantinya akan ditanyakan saat terjun di lapangan.

c. Penyusunan jadwal pelaksanaan proyek

Guru bersama dengan siswa secara kolaboratif menentukan jadwal rangkaian proyek, mulai dari kapan proyek dimulai, pelaksanaan untuk terjun lapangan, tempat berkumpul, hingga presentasi dan deadline pengumpulan laporan proyek kelompok.

d. Penyelesaian proyek dengan fasilitasi dan monitoring guru

Guru memastikan untuk setiap kelompok telah mengkonfirmasi tempat perusahaan jasa sebelum mereka terjun ke lapangan untuk mencari data. Awalnya setiap kelompok diharapkan tidak melakukan observasi di jenis usaha yang sama, namun karena ada beberapa kelompok yang terkendala karena jasa pengiriman barang, hotel dan salon mobil yang sebelumnya telah dipilih oleh masing-masing kelompok tidak mau menerima jika tidak ada surat dari sekolah akhirnya diputuskan bersama bahwa ada beberapa kelompok yang melakukan observasi di jenis usaha yang sama tetapi tempat/pemilik usahanya berbeda. Saat penyelesaian proyek siswa bersama dengan kelompok melakukan penggalian informasi berdasarkan rumusan masalah atau daftar pertanyaan yang sudah dibuat sebelumnya yakni mengenai transaksi deferral dan materi akuntansi 
yang sebelumnya telah mereka pelajari. Waktu yang diberikan guru untuk mencari data sekitar 90 menit, setelah itu siswa harus berkumpul ditempat yang telah disepakati.

e. Penyusunan laporan dan presentasi hasil proyek

Setelah siswa melakukan penggalian data dan informasi, siswa dan guru berkumpul di tempat yang telah ditentukan yaitu pendopo alun-alun. Guru menunjuk beberapa perwakilan kelompok untuk ditanya mengenai data apa saja yang telah diperoleh. Selanjutnya siswa dengan kelompoknya masing-masing berdiskusi menyatukan pendapat sekaligus mulai membuat laporan hasil observasi. Pertemuan selanjutnya yaitu pertemuan ketiga siswa bersama dengan kelompoknya secara bergantian harus menyajikan hasil proyek mereka dengan mempresentasikan di depan kelas.

f. Evaluasi proses dan hasil proyek

Sintaks terakhir yaitu melaksanakan evaluasi proses dan hasil proyek. Sintaks terakhir ini hanya menggali kesan dan pesan siswa mengenai tugas proyek pertama untuk dijadikan tola ukur dan bila ada kekurangan dapat diperbaiki di proyek berikutnya, pengumpulan makalah dan yang terakhir adalah tes untuk mengetahui hasil belajar setelah adanya penerapan model pembelajaran project based learning.

\section{Minat Belajar}

Minat belajar siswa kelas XI IPS 3 SMAN 3 Blitar yang diamati oleh observer melalui aktivitas siswa untuk setiap kelompoknya setelah diterapkan model pembelajaran project based learning dapat dilihat pada tabel 1 berikut.

Tabel 1 Hasil Observasi Minat Belajar Siswa Siklus I

\begin{tabular}{lllllllll}
\hline $\begin{array}{l}\text { Minat Belajar/ Tahapan Project } \\
\text { Based Learning }\end{array}$ & $\mathbf{1}$ & $\mathbf{2}$ & $\mathbf{3}$ & $\mathbf{4}$ & $\mathbf{5}$ & $\mathbf{6}$ & $\mathbf{7}$ & $\mathbf{8}$ \\
\hline $\begin{array}{l}\text { Penentuan Proyek } \\
\text { Kelompok 1 }\end{array}$ & $\checkmark$ & $\checkmark$ & $\checkmark$ & & & & \\
Kelompok 2 & - & - & $\checkmark$ & & & & \\
Kelompok 3 & - & $\checkmark$ & $\checkmark$ & & & & \\
Kelompok 4 & - & $\checkmark$ & $\checkmark$ & & & & \\
Kelompok 5 & $\checkmark$ & $\checkmark$ & $\checkmark$ & & & & \\
Kelompok 6 & - & $\checkmark$ & $\checkmark$ & & & & \\
& & & & & & & \\
\end{tabular}

Perencanaan Langkah-Langkah

Penyelesaian Proyek

Kelompok 1

Kelompok 2

Kelompok 3

Kelompok 4

Kelompok 5

Kelompok 6

$\begin{array}{llll}\checkmark & \checkmark & \checkmark & \checkmark \\ - & \checkmark & \checkmark & - \\ - & \checkmark & \checkmark & \checkmark \\ - & \checkmark & \checkmark & - \\ \checkmark & \checkmark & \checkmark & \checkmark \\ \checkmark & \checkmark & \checkmark & \checkmark\end{array}$

\section{Penyusunan Jadwal Pelaksanaan}

Proyek

Kelompok 1 


\begin{tabular}{|c|c|c|c|c|c|c|c|c|}
\hline $\begin{array}{l}\text { Minat Belajar/ Tahapan Project } \\
\text { Based Learning }\end{array}$ & 1 & 2 & 3 & 4 & 5 & 6 & 7 & 8 \\
\hline $\begin{array}{l}\text { Kelompok } 2 \\
\text { Kelompok } 3 \\
\text { Kelompok } 4 \\
\text { Kelompok } 5 \\
\text { Kelompok } 6\end{array}$ & & $\begin{array}{l}\checkmark \\
\checkmark \\
\checkmark \\
\checkmark \\
\checkmark\end{array}$ & $\begin{array}{l}\checkmark \\
\checkmark \\
\checkmark \\
\checkmark \\
\checkmark\end{array}$ & & & & & \\
\hline $\begin{array}{l}\text { Penyelesaian proyek dengan } \\
\text { fasilitasi dan monitoring guru } \\
\text { Kelompok } 1 \\
\text { Kelompok } 2 \\
\text { Kelompok } 3 \\
\text { Kelompok } 4 \\
\text { Kelompok } 5 \\
\text { Kelompok } 6\end{array}$ & $\begin{array}{l}\checkmark \\
\checkmark \\
\checkmark\end{array}$ & $\begin{array}{l}\checkmark \\
\checkmark \\
\checkmark\end{array}$ & & & & & $\begin{array}{l}\checkmark \\
\checkmark \\
-\end{array}$ & \\
\hline $\begin{array}{l}\text { Penyusunan laporan dan } \\
\text { presentasi/publikasi hasil proyek } \\
\text { Kelompok } 1 \\
\text { Kelompok } 2 \\
\text { Kelompok } 3 \\
\text { Kelompok } 4 \\
\text { Kelompok } 5 \\
\text { Kelompok } 6 \\
\end{array}$ & & & & $\begin{array}{l}\checkmark \\
\checkmark \\
\checkmark \\
\checkmark \\
\checkmark \\
\checkmark\end{array}$ & $\begin{array}{l}\checkmark \\
\checkmark \\
\checkmark \\
\checkmark \\
\checkmark \\
\checkmark\end{array}$ & $\begin{array}{l}\checkmark \\
\checkmark \\
\checkmark \\
\checkmark \\
\checkmark \\
\checkmark\end{array}$ & & $\begin{array}{l}\checkmark \\
- \\
- \\
- \\
\checkmark \\
-\end{array}$ \\
\hline $\begin{array}{l}\text { Evaluasi proses dan hasil proyek } \\
\text { Kelompok } 1 \\
\text { Kelompok } 2 \\
\text { Kelompok } 3 \\
\text { Kelompok } 4 \\
\text { Kelompok } 5 \\
\text { Kelompok } 6 \\
\end{array}$ & & & & $\begin{array}{l}\checkmark \\
\checkmark \\
\checkmark \\
\checkmark \\
\checkmark \\
\checkmark\end{array}$ & & & & \\
\hline
\end{tabular}

Keterangan :
1. Aktivitas Bertanya
2. Aktivitas Mencatat
3. Aktivitas Mendengarkan
4. Aktivitas Diskusi
5. Aktivitas Membuat Laporan
6. Aktivitas Menyajikan Hasil
7. Aktivitas Mengemukakan Fakta atau Prinsip
8. Aktivitas Membuat Keputusan

1) Penentuan Proyek

Dapat dilihat di tabel tersebut saat sintaks pertama minat belajar siswa masih rendah, walaupun semua kelompok sudah nampak aktivitas mendengarkan namun yang tampak bertanya hanya kelompok 1 dan 5 . Lalu kelompok 2 tidak mencatat.

2) Perencanaan Langkah-Langkah Penyelesaian Proyek

Saat sintaks kedua minat belajar siswa per kelompok belum menemui kemajuan yang berarti. Semua kelompok memang melakukan aktivitas mencatat dan mendengarkan. Saat diminta berdiskusi masih ada kelompok yang bingung dan justru diam saja, kelompok tersebut adalah kelompok 2 dan 4. Kelompok yang bertanya juga hanya kelompok 1,5 dan 6. 
3) Penyusunan Jadwal Pelaksanaan Proyek

Aktivitas siswa dari ke 6 kelompok berupa mencatat dan mendengarkan telah nampak pada sintaks project based learning yang ketiga ini.

4) Penyelesaian Proyek dengan Fasilitasi dan Monitoring Guru

Aktivitas siswa yang teramati saat sintaks penyelesaian proyek yaitu semua kelompok telah menunjukkan aktivitas bertanya dan mencatat. Namun di aktivitas ke 7 yaitu mengemukakan fakta atau prinsip kelompok dan kelompok 6 belum menunjukkan aktivitas tersebut.

5) Penyusunan Laporan dan Presentasi/Publikasi Hasil Proyek

Aktivitas kelompok yang teramati pada sintaks ke 5 yaitu memang semua kelompok melakukan aktivitas diskusi, membuat laporan dan menyajikan hasil. Tidak di aktivitas 8 karena kelompok 2,3,4,6 belum dapat membuat keputusan.

6) Evaluasi Proses dan Hasil Proyek

Aktivitas yang tampak pada sintaks terakhir dari project based learning yaitu siswa menyampaikan pesan dan kesan selama kegiatan proyek 1 yang sudah dilakukan. Hal itu juga nantinya akan dijadikan dasar perbaikan bagi guru untuk pelaksanaan proyek selanjutnya. Siswa mengumpulkan hasil proyek berupa makalah kelompok dan melakukan tes evaluasi untuk mengetahui tingkat pemahaman siswa.

Berdasarkan hasil yang diperoleh tersebut siswa belum dikatakan mempunyai minat atau antusias dalam belajar akuntansi melalui penugasan proyek pada siklus I. Hal tersebut bisa dilihat dari aktivitas siswa yang masih sangat kurang saat kegiatan pembelajaran berlangsung.

\section{Hasil Belajar}

Hasil belajar siswa kelas XI IPS 3 SMAN 3 Blitar setelah diterapkan model pembelajaran project based learning pada mata pelajaran akuntansi selama empat kali pertemuan pada siklus I mengalami peningkatan dari sebelum diterapkan model tersebut. Hasil belajar pra tindakan diperoleh dari wawancara dengan guru mata pelajaran.

Berdasarkan hasil dari nilai pra tindakan atau nilai yang didapatkan dari guru mata pelajaran siswa yang tuntas sebelum tindakan sebanyak 9 siswa dan siswa yang tidak tuntas sebanyak 24 siswa dan berdasarkan hasil belajar setelah tindakan siklus I siswa yang tuntas sebanyak 13 siswa dan siswa yang tidak tuntas sebanyak 20 siswa. Hasil belajar diperoleh 
dari penilaian proyek kelompok, komponen yang dinilai antara lain topik, diagram proyek, tahapan proses proyek serta performans/presentasi. Selain dari penilaian kelompok dilakukan tes evaluasi setelah tahapan model project based leraning selesai. Hasil belajar akhir diperoleh dari rata-rata penilaian proyek dan test evaluasi. Berikut hasil rincian hasil belajar siswa yang diperoleh pada siklus I :

Tabel 2 Hasil Belajar Siswa Siklus I

\begin{tabular}{|c|c|c|c|}
\hline Nama & Proyek & Tes & Rata-Rata \\
\hline \multicolumn{4}{|l|}{ Kelompok 1} \\
\hline Anita Meidhiyana & \multirow{5}{*}{88} & 87 & 87 \\
\hline Dandi Nurcahyo & & 64 & 76 \\
\hline Oska Aditya P & & 78 & 83 \\
\hline Respati Wahyu H & & 92 & 90 \\
\hline Rizqi Batik A & & 76 & 82 \\
\hline \multicolumn{4}{|l|}{ Kelompok 2} \\
\hline Adam Malik & \multirow{5}{*}{31} & 64 & 48 \\
\hline Agnestya Citra & & 60 & 46 \\
\hline Mevia Maulydia & & 56 & 44 \\
\hline Primanandya Widdy & & 56 & 44 \\
\hline Rizal Ananda & & 71 & 51 \\
\hline \multicolumn{4}{|l|}{ Kelompok 3} \\
\hline Ba'diatul Munandiyah & \multirow{5}{*}{69} & 86 & 77 \\
\hline Sahara Nera F & & 70 & 69 \\
\hline Virania Regita & & 78 & 73 \\
\hline Putri Purbaning & & 63 & 66 \\
\hline Viona Sadani & & 78 & 73 \\
\hline \multicolumn{4}{|l|}{ Kelompok 4} \\
\hline Nico Primadana & \multirow{6}{*}{75} & 70 & 73 \\
\hline Aura Vanisha & & 77 & 76 \\
\hline Song-Song Wicaksono & & 80 & 78 \\
\hline Bayu Amar Ma'ruf & & 66 & 71 \\
\hline Celvin Cahya Primadika & & 76 & 76 \\
\hline Calvin Panji Samodro & & 78 & 77 \\
\hline \multicolumn{4}{|l|}{ Kelompok 5} \\
\hline Adinda Paramitha T.K. & \multirow{5}{*}{81} & 90 & 86 \\
\hline Erlin Epriliyanti & & 76 & 79 \\
\hline Nina Reza Marsha D & & 82 & 82 \\
\hline Sefira Rahmawati & & 76 & 79 \\
\hline Andyar Luthfi S & & 82 & 82 \\
\hline \multicolumn{4}{|l|}{ Kelompok 6} \\
\hline Dhimas Dwiki Atmaja & \multirow{6}{*}{63} & 81 & 72 \\
\hline Elcinta Fridaynia Y.N. & & 80 & 71 \\
\hline Lala Dwi Anggita & & 73 & 68 \\
\hline Lusi Liyana Melati & & 80 & 71 \\
\hline Vrada Ammar Maulida & & 76 & 69 \\
\hline Mukhamad Rizqi Fajar & & 76 & 69 \\
\hline
\end{tabular}

Dari hasil belajar yang didapat dari guru mata pelajaran dan tes setelah dilakukan tindakan dapat dilihat bahwa hasil belajar siswa terjadi peningkatan yang belum signifikan. 
Tabel 3 Ketuntasan Belajar Siswa pada Siklus I

\begin{tabular}{clcc}
\hline \multicolumn{1}{c}{ Tes } & \multicolumn{1}{c}{$\begin{array}{c}\text { Ketuntasan } \\
\text { Belajar }\end{array}$} & $\sum$ Siswa & $\sum$ Seluruh Siswa \\
\hline Pra Tindakan & Tuntas & 9 & 33 \\
& Tidak Tuntas & 24 & 33 \\
Tes Evaluasi & Tuntas & 13 & 33 \\
& Tidak Tuntas & 20 & 33 \\
\hline
\end{tabular}

Berdasarkan tabel 2 dapat diketahui bahwa persentase keberhasilan belajar siswa masih $\leq 75 \%$. Sedangkan kriteria keberhasilan dari penelitian yaitu hasil perhitungan belajar siswa harus menunjukkan $\geq 75 \%$ siswa berada dalam kategori minimal baik. Dapat disimpulkan bahwa pada siklus I belum terpenuhi sehingga tindakan akan diulang pada siklus II.

\section{Refleksi}

Rangkaian pembelajaran siklus I sudah mengalami peningkatan minat dan hasil belajar dibandingkan saat pra tindakan. Hal tersebut dibuktikan meningkatnya aktivitas belajar di kelas, dimana siswa lebih aktif saat kegiatan pembelajaran menggunakan model project based learning berlangsung, siswa dapat mengkonstruk pengetahuan mereka dan peran guru hanya sebagai fasilitator. Namun pada siklus I masih terdapat kekurangan diantaranya yaitu masih ada siswa yang bingung mengenai tugas proyek yang diberikan dan penyusunan laporannya dikarenakan guru kurang memberikan ilustrasi dan format laporan tertulis, selain itu guru kurang memberikan apresiasi dan motivasi sehingga saat terjun lapangan mayoritas kelompok kurang menunjukkan adanya kerja sama saat menyelesaikan tugas proyek dan mereka kurang percaya diri saat menampilkan hasil proyeknya. Kekurangan yang ada di siklus I akan menjadi evaluasi dan diperbaiki di siklus II sehingga diharapkan nantinya hasil yang diperoleh pada siklus II lebih meningkat.

Berdasarkan hasil yang diperoleh pada siklus I masih perlu adanya perbaikan sehingga dilanjutkan ke siklus II, dapat diketahui hasil yang diperoleh sebagai berikut.

\section{Tahapan Project Based Learning Siklus II}

Berdasarkan paparan data dalam tindakan siklus II, dapat diketahui hasil yang diperoleh adalah sebagai berikut.

a. Penentuan Proyek

Tahapan Project Based Learning yang pertama yaitu penentuan proyek. Setelah guru menjelaskan materi mengenai jurnal penyesuaian yang berkaitan dengan transaksi akrual disertai dengan banyak contoh ilustrasi. Guru meminta siswa untuk berkumpul bersama 
dengan kelompok yang sama saat rangkaian proyek 1 dan menjelaskan tugas untuk proyek 2.

b. Perencanaaan langkah-langkah penyelesaian proyek

Saat ini guru memastikan siswa berdiskusi dan benar-benar menyiapkan daftar pertanyaan atau rumusan masalah yang akan ditanyakan tidak seperti pada proyek 1 masih ada kelompok yang pertanyaannya justru tidak terkait dengan jurnal penyesuaian. Guru juga memotivasi siswa untuk dapat kompak dan dapat saling bekerja sama di rangkaian proyek 2 ini sehingga nantinya hasil yang didapat juga akan maksimal.

c. Penyusunan jadwal pelaksanaan proyek

Guru bersama dengan siswa secara kolaboratif menentukan jadwal rangkaian proyek, mulai dari kapan proyek dimulai, pelaksanaan untuk terjun lapangan, tempat berkumpul, hingga presentasi dan deadline pengumpulan laporan proyek kelompok.

d. Penyelesaian proyek dengan fasilitasi dan monitoring guru

Tahapan ini sama dengan rangkaian proyek sebelumnya yaitu siswa bersama dengan kelompoknya harus melakukan penggalian informasi berdasarkan rumusan masalah atau daftar pertanyaan yang sudah dibuat sebelumnya yakni mengenai transaksi akrual. Waktu yang diberikan guru untuk mencari data sekitar 90 menit, setelah itu siswa harus berkumpul ditempat yang telah disepakati.

e. Penyusunan laporan dan presentasi hasil proyek

Pertemuan kedua setelah siswa melakukan pencarian informasi, siswa dan guru berkumpul di tempat yang telah ditentukan yaitu pendopo alun-alun. Siswa dengan kelompoknya masing-masing berdiskusi menyatukan pendapat sekaligus mulai membuat laporan hasil observasi karena pada pertemuan selanjutnya nanti siswa bersama dengan kelompoknya secara bergantian harus menyajikan hasil proyek mereka dengan mempresentasikan di depan kelas.

f. Evaluasi proses dan hasil proyek

Pertemuan keempat yaitu melaksanakan evaluasi proses dan hasil proyek. Sintaks terakhir ini hanya menggali kesan dan pesan siswa mengenai proyek yang sudah dikerjakan selama ini, pengumpulan makalah dan yang terakhir adalah tes untuk mengetahui hasil belajar setelah adanya penerapan model pembelajaran project based learning. 


\section{Minat Belajar}

Minat belajar siswa kelas XI IPS 3 SMAN 3 Blitar yang diamati oleh observer melalui aktivitas siswa untuk setiap kelompoknya setelah diterapkan model pembelajaran project based learning dapat dilihat pada tabel 3 berikut

Tabel 4 Hasil Observasi Minat Belajar Siklus II

\begin{tabular}{lcccccccc}
$\begin{array}{l}\text { Minat Belajar/ Tahapan Project } \\
\text { Based Learning }\end{array}$ & 1 & $\mathbf{2}$ & $\mathbf{3}$ & $\mathbf{4}$ & $\mathbf{5}$ & $\mathbf{6}$ & $\mathbf{7}$ & $\mathbf{8}$ \\
\hline Penentuan Proyek & $\checkmark$ & $\checkmark$ & $\checkmark$ & & & & \\
Kelompok 1 & - & $\checkmark$ & $\checkmark$ & & & & \\
Kelompok 2 & $\checkmark$ & $\checkmark$ & $\checkmark$ & & & & & \\
Kelompok 3 & $\checkmark$ & $\checkmark$ & $\checkmark$ & & & & & \\
Kelompok 4 & $\checkmark$ & $\checkmark$ & $\checkmark$ & & & & \\
Kelompok 5 & - & $\checkmark$ & $\checkmark$ & & & & & \\
Kelompok 6 & & & & & & & & \\
\hline
\end{tabular}

Perencanaan Langkah-Langkah

Penyelesaian Proyek

Kelompok 1

Kelompok 2

Kelompok 3

Kelompok 4

Kelompok 5

Kelompok 6

$\begin{array}{llll}\checkmark & \checkmark & \checkmark & \checkmark \\ - & \checkmark & \checkmark & - \\ \checkmark & \checkmark & \checkmark & \checkmark \\ \checkmark & \checkmark & \checkmark & \checkmark \\ \checkmark & \checkmark & \checkmark & \checkmark \\ \checkmark & \checkmark & \checkmark & \checkmark\end{array}$

Penyusunan Jadwal Pelaksanaan

Proyek

Kelompok 1

Kelompok 2

Kelompok 3

Kelompok 4

Kelompok 5

Kelompok 6

Penyelesaian proyek dengan

fasilitasi dan monitoring guru

Kelompok 1

Kelompok 2

Kelompok 3

Kelompok 4

Kelompok 5

Kelompok 6

Penyusunan laporan dan

presentasi/publikasi hasil proyek

Kelompok 1

Kelompok 2

Kelompok 3

Kelompok 4

Kelompok 5

Kelompok 6

$\begin{array}{ll}\checkmark & \checkmark \\ \checkmark & \checkmark \\ \checkmark & \checkmark \\ \checkmark & \checkmark \\ \checkmark & \checkmark \\ \checkmark & \checkmark\end{array}$

Evaluasi proses dan hasil proyek

Kelompok 1

Kelompok 2

Kelompok 3

Kelompok 4

Kelompok 5

I. Kelompok 6 
Keterangan :

1. Aktivitas Bertanya

2. Aktivitas Mencatat

3. Aktivitas Mendengarkan

4. Aktivitas Diskusi

5. Aktivitas Membuat Laporan

6. Aktivitas Menyajikan Hasil

7. Aktivitas Mengemukakan Fakta atau Prinsip

8. Aktivitas Membuat Keputusan

1) Penentuan Proyek

Dapat dilihat di tabel tersebut saat sintaks pertama minat belajar siswa maeningkat dari siklus I. Hampir semua kelompok melakukan aktivitas hanya kelompok 2 dan 6 yang tidak bertanya. Sedangkan kelompok lain sudah terlihat aktivitas mendengarkan, bertanya dan mencatat.

2) Perencanaan Langkah-Langkah Penyelesaian Proyek

Saat sintaks kedua minat belajar siswa per kelompok belum sudah mengalami kenaikan yang signifikan. Semua kelompok kecuali kelompok 2 melakukan aktivitas mencatat, mendengarkan, mendengarkan dan berdiskusi.

3) Penyusunan Jadwal Pelaksanaan Proyek

Aktivitas siswa dari ke 6 kelompok berupa mencatat dan mendengarkan telah nampak pada sintaks project based learning yang ketiga ini.

4) Penyelesaian Proyek dengan Fasilitasi dan Monitoring Guru

Aktivitas siswa yang teramati saat sintaks penyelesaian proyek yaitu semua kelompok telah menunjukkan aktivitas bertanya, mencatat dan kesemuanya sudah menunjukkan aktivitas mengemukakan fakta atau prinsip.

5) Penyusunan Laporan dan Presentasi/Publikasi Hasil Proyek

Aktivitas kelompok yang teramati pada sintaks ke 5 yaitu memang semua kelompok melakukan aktivitas diskusi, membuat laporan,menyajikan hasil serta sudah dapat membuat keputusan.

6) Evaluasi Proses dan Hasil Proyek

Aktivitas yang tampak pada sintaks terakhir dari project based learning yaitu siswa menyampaikan pesan dan kesan selama kegiatan proyek yang sudah dilakukan. Siswa mengumpulkan hasil proyek berupa makalah kelompok dan melakukan tes evaluasi untuk mengetahui tingkat pemahaman siswa. 


\section{Hasil Belajar}

Hasil belajar siswa kelas XI IPS 3 SMAN 3 Blitar setelah diterapkan model pembelajaran problem based learning pada mata pelajaran akuntansi selama empat kali pertemuan pada siklus II mengalami peningkatan dari siklus I.

Berdasarkan hasil dari nilai yang didapatkan pada tes dan nilai proyek (makalah kelompok) yang dilakukan pada siklus I siswa yang tuntas sebanyak 13 siswa dan siswa yang tidak tuntas sebanyak 21 siswa dan berdasarkan hasil tes setelah tindakan pada siklus II siswa yang tuntas sebanyak 28 siswa dan siswa yang tidak tuntas sebanyak 5 siswa. Dari hasil belajar yang didapat dari guru mata pelajaran dan tes setelah dilakukan tindakan dapat dilihat bahwa hasil belajar siswa terjadi peningkatan atau dapat dikatakan bahwa hasil belajar siswa pada siklus II dalam kategori baik. Berikut hasil rincian hasil belajar siswa yang diperoleh pada siklus I :

\section{Tabel 5 Hasil Belajar Siklus II}

\begin{tabular}{|c|c|c|c|}
\hline Nama & Proyek & Tes & Rata-Rata \\
\hline \multicolumn{4}{|l|}{ Kelompok 1} \\
\hline Anita Meidhiyana & \multirow{5}{*}{94} & 95 & 94 \\
\hline Dandi Nurcahyo & & 78 & 76 \\
\hline Oska Aditya P & & 78 & 86 \\
\hline Respati Wahyu H & & 94 & 94 \\
\hline Rizqi Batik A & & 82 & 88 \\
\hline \multicolumn{4}{|l|}{ Kelompok 2} \\
\hline Adam Malik & \multirow{5}{*}{56} & 78 & 67 \\
\hline Agnestya Citra & & 76 & 66 \\
\hline Mevia Maulydia & & 66 & 61 \\
\hline Primanandya Widdy & & 66 & 61 \\
\hline Rizal Ananda & & 66 & 61 \\
\hline \multicolumn{4}{|l|}{ Kelompok 3} \\
\hline Ba'diatul Munandiyah & \multirow{5}{*}{88} & 90 & 89 \\
\hline Sahara Nora F & & 76 & 82 \\
\hline Virania Regita & & 84 & 86 \\
\hline Putri Purbaning & & 78 & 83 \\
\hline Viona Sadani & & 78 & 83 \\
\hline \multicolumn{4}{|l|}{ Kelompok 4} \\
\hline Nico Primadana & \multirow{6}{*}{88} & 80 & 84 \\
\hline Aura Vanisha & & 80 & 84 \\
\hline Song-Song Wicaksono & & 85 & 86 \\
\hline Bayu Amar Ma'ruf & & 88 & 78 \\
\hline Celvin Cahya Primadika & & 76 & 82 \\
\hline Calvin Panji Samodro & & 80 & 84 \\
\hline \multicolumn{4}{|l|}{ Kelompok 5} \\
\hline Adinda Paramitha T.K. & \multirow{5}{*}{88} & 94 & 91 \\
\hline Erlin Epriliyanti & & 76 & 82 \\
\hline Nina Reza Marsha D & & 82 & 85 \\
\hline Sefira Rahmawati & & 76 & 82 \\
\hline Andyar Luthfi S & & 88 & 88 \\
\hline \multicolumn{4}{|l|}{ Kelompok 6} \\
\hline Dhimas Dwiki Atmaja & \multirow{4}{*}{81} & 81 & 81 \\
\hline Elcinta Fridaynia Y.N. & & 90 & 86 \\
\hline Lala Dwi Anggita & & 82 & 82 \\
\hline Lusi Liyana Melati & & 86 & 84 \\
\hline
\end{tabular}




\begin{tabular}{|c|c|c|c|}
\hline Nama & Proyek & Tes & Rata-Rata \\
\hline Vrada Ammar Maulida & & 80 & 81 \\
\hline Mukhamad Rizqi Fajar & & 76 & 79 \\
\hline
\end{tabular}

Tabel 6 Ketuntasan Belajar Siswa pada Siklus I dan II

\begin{tabular}{llcc}
\hline \multicolumn{1}{c}{ Tes } & Ketuntasan Belajar & $\sum$ Siswa & $\sum$ Seluruh Siswa \\
\hline Pra Tindakan & Tuntas & 9 & 33 \\
Tes Evaluasi & Tidak Tuntas & 24 & 33 \\
Siklus I & Tuntas & 13 & 33 \\
Tes Evaluasi & Tidak Tuntas & 20 & 33 \\
Siklus II & Tidak Tuntas & 28 & 33 \\
\hline
\end{tabular}

Berdasarkan hasil belajar siswa yang diperoleh dari proyek kelompok dan tes evaluasi yang dilakukan setelah tindakan pada siklus II, hanya terdapat 5 siswa masih belum tuntas atau masih dibawah KKM yaitu 76 dan 28 siswa. Dapat disimpulkan bahwa kegiatan pada siklus II sudah terpenuhi sehingga tindakan dihentikan pada siklus II.

\section{PEMBAHASAN}

Proses pembelajaran dengan model pembelajaran project based learning pada tiap siklus minat belajar siswa sudah mengalami peningkatan. Banyak siswa yang telah memiliki antusiasme dan semangat untuk belajar, hal ini dibuktikan dengan meningkatnya aktivitas siswa si setiap sintaks project based learning. Aktivitas tersebut antara lain bertanya, mencatat, mendengarkan, diskusi, membuat laporan, menyajikan hasil serta mengemukakan fakta.

Sintaks penentuan proyek pada siklus I siswa masih jarang ada yang bertanya namun saat siklus II siswa mayoritas kelompok selain melakukan aktivitas mendengarkan dan mencatat mereka sudah berani untuk bertanya. Hal tersebut disebabkan karena siswa sudah mulai terbiasa dan tidak malu untuk bertanya. Sintaks perencanaan langkah-langkah penyelesaian proyek aktivitas yang muncul masing-masing adalah mencatat, mendengarkan, dan berdiskusi pada saat siklus I aktivitas di sintaks kedua ini belum semua muncul karena masih ada kelompok yang tidak mendengarkan atau melakukan diskusi tetapi di siklus II semua aktivitas tersebut dapat muncul dikarenakan selain sudah terbiasa saat proyek 1 siswa sudah berani dan percaya diri untuk mengemukakan pendapat di kelompoknya masingmasing. Sintaks ketiga yaitu penyusunan jadwal pelaksanaan proyek, baik di siklus I maupun siklus II semua kelompok mendengarkan dan memperhatikan penjelasan proyek dari guru hal tersebut menunjukkan bahwa siswa mempunyai ketertarikan dan rasa ingin tahu mengenai tugas proyek yang diberikan. Sintaks keempat yaitu penyelesaian proyek dimana siswa mulai 
mencari data, saat siklus I dan II aktivitas yang sering muncul adalah bertanya dan mencatat, hal tersebut dikarenakan semua kelompok aktif bertanya pada narasumber, mencatat informasi saat melakukan pencarian informasi di perusahaan jasa tetapi untuk aktivitas mengemukakan fakta masih belum semua kelompok dapat melakukan, hal tersebut disebabkan karena daya serap materi antar kelompok berbeda. Sintaks kelima yaitu penyusunan laporan dan presentasi proyek, pada tahap ini siswa mulai berdiskusi untuk membuat laporan hasil proyek setelah itu dipresentasikan secara bergantian. Aktivitas yang muncul pada yaitu diskusi, membuat laporan dan menyajikan hasil. Aktivitas tersebut muncul karena siswa antusias dalam menyusun laporan dan bertukar pendapat dengan anggota kelompoknya. Tetapi masih ada yang salah konsep atau bahkan tidak berpendapat sama sekali. Berbanding terbalik saat siklus II semua kelompok aktif dalam melakukan kegiatan diskusi, membuat laporan, menyajikan hasil dan membuat keputusan. Hal tersebut dapat terjadi karena kelompok sudah menguasai materi dan dapat bekerja sama dengan baik. Sintaks terakhir yaitu evaluasi hasil proyek, tahapan ini guru dan siswa pada akhir proses pembelajaran melakukan refleksi terhadap aktivitas dan hasil tugas proyek yang telah terselesaikan siswa-siswa tersebut pada siklus I awalnya ragu untuk menyampaikan tetapi saat siklus II mereka menceritakan pengalamannya dengan lancar dan antusias.

Aktivitas yang muncul pada semua tahapan pembelajaran berbasis proyek menunjukkan adanya minat atau ketertarikan siswa dalam bentuk yang beragam. Meningkatnya aktivitas tersebut menunjukkan tumbuhnya minat siswa terhadap pembelajaran berbasis proyek.

Hasil penelitian ini sejalan dengan hasil penelitian yang dilakukan oleh Dedy (2013) yaitu model pembelajaran berbasis proyek dapat meningkatkan motivasi belajar siswa karena siswa mampu melakukan penelitian pada dunia nyata dan belajar pada orang yang memiliki kecakapan relevan.

Hal ini sesuai dengan teori yang dikemukakan oleh Hidi \& Harackiewicz (2000) siswa yang tertarik pada apa yang mereka pelajari menunjukkan prestasi akademik yang lebih tinggi dan lebih mungkin mengingat materi tersebut dalam jangka panjang. Begitu juga dengan penelitian yang dilakukan oleh Dedy Kurnianto (2013) "Implementasi Strategi Pembelajaran Kreatif Produktif dengan Model Pembelajaran Berbasis Proyek untuk Meningkatkan Motivasi Belajar Siswa Kelas X Akuntansi 2 SMK YPKK 1 Sleman”. Hasil dari penelitian Hasil penelitian menunjukkan bahwa terjadi peningkatan skor motivasi belajar 
akuntansi dari sebelum implementasi strategi pembelajaran kreatif produktif dengan model pembelajaran berbasis proyek.

Selanjutnya melaksanakan proses pembelajaran dengan model pembelajaran project based learning pada tiap siklus hasil belajar siswa sudah mengalami peningkatan. Hal tersebut dapat dilihat saat pembelajaran berlangsung siswa dapat menjawab pertanyaan yang diberikan oleh guru. Selain itu siswa juga berpartisipasi penuh saat proses pembelajaran, karena dalam model ini siswa dituntut agar dapat mengkonstruk pengetahuan mereka dan berusaha untuk menemukan alternatif pemecahan masalah yang ada du dunia nyata dengan melakukan observasi kecil di perusahaan jasa mengenai materi jurnal penyesuaian untuk transaksi pos deferral dan akrual. Setiap anggota kelompok memiliki tanggung jawab masingmasing dalam mengerjakan tugas proyek, sehingga tidak ada siswa yang dianggap menumpang kepada anggota kelompok lainnya.

Hasil belajar ini difokuskan pada aspek kognitif dan ketrampilan yang diambil dari nilai proyek kelompok lalu di rata-rata. Siklus I mendapatkan ketuntasan beajar klasikal 40\%. Terjadi peningkatan hasil belajar rata-rata dari siklus I dan siklus II. Pada siklus II berdasarkan analisis data terhadap hasil belajar siswa menunjukkan nilai tes evaluasi siswa dengan ketuntasan belajar klasikal sebesar $85 \%$.

Sesuai dengan teori yang dikemukakan oleh Dimyati dan Mudjiono (2006:20) mengungkapkan bahwa "hasil belajar merupakan puncak proses belajar, sedangkan belajar adalah seperangkat proses kognitif yang mengubah sifat stimulus lingkungan, dengan melewati pengolahan informasi menjadi kapabilitas baru". Begitu juga dengan pendapat Sardirman (2007:84) "Hasil belajar atau prestasi belajar akan menjadi optimal kalau ada motivasi. Semakin tepat motivasi yang diberikan, akan semakin berhasil pula pelajaran itu”. Jadi hasil belajar yang diperoleh siswa XI IPS 3 SMAN 3 Blitar ini merupakan nilai yang diperoleh siswa setelah guru menerapkan model project based learning

\section{SIMPULAN}

Berdasarkan hasil penelitian dan pembahasan yang telah diuraikan sebelumnya, diperoleh kesimpulan sebagai berikut: (1) Terdapat peningkatan minat belajar siswa kelas XI IPS 3 SMA Negeri 3 Blitar dengan menerapkan model Project Based Learning. Hal ini terbukti dari peningkatan aktivitas siswa saat mengikuti rangkaian pembelajaran. Yaitu siswa sudah berani bertanya, mendengarkan penjelasan dari guru maupun saat penggalian informasi dengan narasumber, mencatat hal-hal yang dirasa perlu, saling berdiskusi antar anggota 
kelompok untuk menyelesaikan tugas proyek, berkolaborasi dalam membuat laporan proyek, menyajikan hasil proyek secara berkelompok, serta dapat mengemukakan fakta yang didapat di lapangan untuk selanjutnya bisa menarik kesimpulan. Meningkatnya aktivitas tersebut berdampak pada meningkatnya minat belajar siswa pada kelas XI IPS 3. (2) Hasil belajar siswa kelas XI IPS 3 SMA Negeri 3 Blitar meningkat setelah pelaksanaan model Project Based Learning. Ketuntasan belajar klasikal pada siklus I sebesar $40 \%$ dan untuk siklus II memperoleh ketuntasan belajar klasikal sebesar $85 \%$.

Dengan memperhatikan hasil temuan dalam penelitian ini, maka dalam kesempatan ini penulis bermaksud menyampaikan saran-saran. (1) Diharapkan saat penggunaan model pembelajaran ini guru juga dapat mengantisipasi jika saat pelaksanaan proyek siswa tidak bisa dipantau secara berkelompok. Bisa dengan mengirimkan video wawancara ataupun rekaman suara saat menggali informasi di tempat observasi. (2) Kepada para guru jika akan menggunakan model Project Based Learning dalam proses pembelajaran harus bisa mematangkan konsep dan materi kepada siswa, sehingga siswa nantinya tidak bingung saat harus mengkaitkan konsep dengan kehidupan nyata saat pengerjaan proyek. (3) Diharapkan untuk penelitian selanjutnya agar dapat menuliskan secara rinci mengenai tugas proyek beserta langkah-langkah yang harus dilakukan oleh siswa.(4) Peneliti selanjutnya juga diharapkan dapat memperbaiki format laporan hasil proyek agar lebih merujuk langsung pada tahapan model pembelajaran Project Based Learning.

\section{DAFTAR RUJUKAN}

Abidin, Yunus. (2014). Desain Sisitem Pembelajaran dalam Konteks Kurikulum 2013. Bandung: PT Refika Aditama.

Dimyati dan Moedjiono. (2009). Belajar dan Pembelajaran. Jakarta: Rineka Cipta.

Fathurrohman, Muhammad. (2015). Model-Model Pembelajaran Inovatif. Yogyakarta: ArRuzz Media.

Harsono. (2006). Kearifan dalam Transformasi Pembelajaran dari Teacher-Centered ke Student-Centered Learning. Jurnal Penelitian Kedokteran dan Profesi Kesehatan, 3(1), (Online), (http://luk.staff.ug,.ac.id/), diakses 8 Januari 2016.

Hidi, S., \& Harackiewicz, J.M. (2000). Motivating The Academically Unmotivated: A Critical Issue for The $21^{\text {st }}$ century Review of Educational Research.

Ormrod, Jeanne Ellis. (2009). Psikologi Pendidikan: Membantu Siswa Tumbuh dan Berkembang (Rikard Rahmat, Ed.). Jakarta: Erlangga.

Sardirman, A. M. (2007). Interaksi dan Motivasi Belajar Mengajar. Jakarta: Rajawali Grafindo Persada.

Slameto. (2010). Belajar dan Faktor-faktor yang Mempengaruhinya. Jakarta: Rineka Cipta.

Sugiyono. (2009). Metode Penelitian Bisnis (Pendekatan Kuantitatif, Kualitatif, dan R\&D). Bandung: Alfabeta. 
Sukmadinata, Nana Syaodih. (2004). Metode Penelitian Pendidikan. Bandung: Remaja Rosdakarya. 